Published in: Art History Vol. 28 No. 4 (Autumn 2005) pp. 524-51.

\title{
Art History and Cultural Difference: Alfred Gell's Anthropology of Art
}

\author{
Matthew Rampley
}

One of the most pressing issues currently confronting the theory and history of art is the question of cultural difference. Specifically, what are the implications of the difference between western and non-Western cultures for the task of visual and artistic analysis? In what ways is it possible to undertake cross-cultural analysis while remaining within the frame of art history - a set of discourses originally formulated to account for the development of Western art?

The responses to this question have been varied, ranging from an emphasis on the complete incommensurability of different cultures to ambitious attempts at constructing world art histories. In this article I examine the work of one particular author - the anthropologist Alfred Gell (1945-1997) - and his contribution to discussion on this issue. As I argue, Gell offers some potentially significant ways of rethinking this question, and specifically, his work offers the outline of a possible form of cross-cultural analysis that avoids some of the pitfalls that have beset previous such attempts. I analyse Gell in detail shortly, but before doing so, offer a brief overview of the current state of critical debate on the issue.

Questions of Cultural Difference 
Published in: Art History Vol. 28 No. 4 (Autumn 2005) pp. 524-51.

At the root of the topic of cultural difference are a number of inter-related questions. In particular: to what extent is it possible to refer to art as a cross-cultural category? Further: to what extent is it possible to speak of aesthetic judgement and value as cross-cultural categories and, finally, to what extent is it possible to construct a cross-cultural history of art? The histories of art of the nineteenth century which, from Hegel onwards, attempted to encompass all art within a single universal narrative, have long been recognised as deeply problematic. ${ }^{1}$ Although they have persisted into the twentieth century, this is now mostly a matter of pedagogical and organisational convenience, rather than being based on any larger, substantive claim about the common developmental logic of world $\operatorname{art}^{2}$ Perhaps the last attempt to construct a comprehensive history of art around a single narrative thread was Ernst Gombrich's History of Art, first published in 1950, yet subsequently Gombrich proved to be one of the most trenchant critics of Hegel and the legacy of Hegelianism in art history. ${ }^{3}$

While such universal histories of art can be regarded largely as a historical relic from an earlier phase in the discipline's development, historical scholarship on non-Western art has, in contrast, flourished. Until recently the legitimacy of art history as a frame of analysis has, on the whole, been uncontested; at stake have merely been questions of relative cultural and aesthetic value. Relativism has played an important role in scrutinising the values implicit in art historical judgements, but it has left the category of 'art' untouched. When the latter is also subjected to analysis, more disturbing problems are then raised. The category of 'art' presents difficulties both in terms of the pragmatics of non-Western art histories and also in terms of the sociological and philosophical recognition of its cultural 
Published in: Art History Vol. 28 No. 4 (Autumn 2005) pp. 524-51.

and historical specificity. Hence, scholarship on non-Western art is faced with a domain of objects that do not equate with the practices that were the traditional object of European and American art history. Thus 'Japanese art,' for example, comprises, as well as the more familiar media of print, painting, sculpture and architecture, suits of armour, ceramic, bronze and wood vessels, gardens, furniture and dress, none of which figure in traditional histories of Western art. ${ }^{4}$ Moreover this lack of 'fit' does not indicate the existence of a distinct notion of art in Japan; it is a function of the reverse, namely, the lack of an overarching conception of 'art' in pre-modern Japanese society and hence the difficulties raised when the Western observer attempts to construct one. A similar problem can be observed in accounts of art in South Asia, which focus on sculpture, architecture and painting to the exclusion of dance and music, for example, even though the latter are as significant a part of visual culture as work in other media. ${ }^{5}$

Such comparisons heighten the sense of the specificity of art as a category of analysis; emerging in Europe during the Renaissance, it gained institutional and philosophical legitimation in the eighteenth century through both the reduction of the various disparate arts to one single principle, and also the highlighting of the particular kind of experience aesthetic - prompted by the encounter with art. $^{6}$ This latter issue is of key importance, for it addresses both cross-cultural viability of the concept of aesthetic experience and also its role in the understanding of art. In the wake of the work of Pierre Bourdieu and others it has been widely accepted that despite claims to the universality of aesthetic judgement, it is in fact a product of the European and North American Enlightenment, an inflexion of bourgeois ideologies of freedom and autonomy. ${ }^{7}$ Consequently, the idea of aesthetic 
Published in: Art History Vol. 28 No. 4 (Autumn 2005) pp. 524-51.

experience is alien to most (but not all) non-Western cultures, a view that has led to stress on the embeddedness of art within broader cultural values and meanings that outstrip purely aesthetic appearance. ${ }^{8}$ Hence, judgements that initially appear to approximate to the aesthetic concerns of the Western observer are in fact deeply imbricated in wider social, political and religious values.

This last point is crucial, for traditional histories of non-Western art - and studies in the cognate field of the anthropology of art - have been concerned primarily with the articulation and analysis of the aesthetic value system motivating the production and reception of artworks (I leave aside for the moment the problematic question of the definition of 'artwork'). Such a conception also views artworks as instances of an a priori general set of aesthetic codes and values. In contrast, however, not only does 'art' turn out to be an elusive cultural category, with no evident commensurability between different societies in terms of its object domain, but also assumptions about the aesthetic basis of art become open to question.

Recently, a further criticism of the idea of global art history has been articulated by James Elkins, and this turns on the question of historicity. ${ }^{9}$ The idea of a developmental history has been central to the self-understanding of European art since the Renaissance - and possibly also in classical antiquity - and this has also framed accounts of non-Western art. ${ }^{10}$ These have often relied on periodisation and tracing of developmental sequences of styles in order to map out the art historical terrain. Yet as Elkins has pointed out, this is distinctive to Europe and North America; for most cultures the idea of a history of art is alien. In 
Published in: Art History Vol. 28 No. 4 (Autumn 2005) pp. 524-51.

societies where art is an adjunct of, for example, religion, the idea of a specifically artistic history is meaningless; in others, and he cites the example of the late-sixteenth century Persian writer Qādī Ahmad's manuscript Calligraphers and Painters (ca. 1596-97), there may be a sense of a tradition of artists, but this takes the form of a chronicle, rather than a notion of progressive endeavour. ${ }^{11}$

The common thread to all of these criticisms has thus been an emphasis on cultural incommensurability and difference, and they have been part of what has been referred to more generally - and erroneously - as the ethnographic turn. ${ }^{12}$ If accepted, they make for troubling reading, for they challenge the legitimacy of vast areas of established and widely disseminated scholarship. They also close off the possibilities of cross-cultural dialogue, for implicit is the notion that certain cultural differences are so vast, their traditions so incommensurable, as to present an unbridgeable gap between the (Western) observer and the observed.

Such a stress on cultural incommensurability has itself been subject to scrutiny, however. In his study of image-making in sixteenth-century China, for example, Craig Clunas has argued, that there were distinct parallels between China and Renaissance Italy in terms of the cultural meaning and value of painting; paintings were valued commodities, exchanged by means of a complex art market and supported by a tradition of connoisseurship. ${ }^{13}$ In China there was also a flourishing enterprise in the production of copies and counterfeits of celebrated paintings, indicating a conception of a canonical tradition of masterworks, accompanied by an equal concern with the authenticity of artworks that displays important 
Published in: Art History Vol. 28 No. 4 (Autumn 2005) pp. 524-51.

similarities with the contemporary situation in Italy and elsewhere in Europe. Similar comparative studies have explored parallels with sixteenth and seventeenth-century Japan, while the profession of artist has proven as amenable to analysis in the Chinese context as the professional art world of the West. ${ }^{14}$ In other words, it is possible to overstate cultural differences and ignore substantial commonalities, in terms of both the cultural value and meaning ascribed to art, and also its social and political function. The employment of art in the construction of national identities, for example, can be observed as clearly in eighteenth-century Japan as it can in Europe and America. ${ }^{15}$

There have also been significant recent renewed attempts to construct cross-cultural aesthetics and art histories. Richard Anderson's Calliope's Sisters undertakes the ambitious project of a comparative study of, for example, Aztec, Navajo, Inuit and Yoruba aesthetic systems in order to support a general thesis about the cross-cultural applicability of the notions of art and aesthetic judgement, even though aesthetic values may be specific to each culture. ${ }^{16}$ Despite considerable cultural differences, the common factor is the skilful encoding of culturally significant meaning in sensuous form. What distinguish art from non-art are its semantic density and its referential character. As Anderson states:

$\ldots$ in addition to an art work's being "about" its own stylistic conventions and the emotional response that its use of a sensuous medium can evoke, it is also "about" some subject in the sociocultural matrix of which it is a part. $^{17}$ 
Published in: Art History Vol. 28 No. 4 (Autumn 2005) pp. 524-51.

More recently, David Summers' vast study Real Spaces has attempted to lay the groundwork of a 'post-formalist' art history by reference to the phenomenology of Martin Heidegger and Maurice Merleau-Ponty. ${ }^{18}$ For Summers the fundamental basis of a world art history is the role of art in articulating embodied experience, and in particular the experience of space. This may occur either in terms of real space - as in the case of architecture - or virtual space - as in the case of images.

These accounts lay down an important challenge to the emerging consensus that privileges cultural difference over commensurability. However, the difficulty with both is that what they identify as the cross-cultural basis of analysis is so open and generalised as to be easily overwritten (and hence lost) by the specificities of each individual culture. Understanding of the sociocultural matrix that is the object of art for Anderson may vary so much between cultures as still to result in incommensurable practices. Likewise, the embodied experience of space emphasised by Summers may be given completely incommensurate symbolic articulations in different cultures. There is also no guarantee that what Summers identifies as the basic character of embodied space is not itself a culturally specific projection. ${ }^{19}$

Yet if such renewed attempts to establish some form of global aesthetics or art history face important difficulties, the emphasis on cultural incommensurability is equally problematic. Its radical particularism, stressing the absolute heterogeneity and incommensurability of visual practices of different cultures, militates against the possibility of comparison to highlight either similarities or differences. As Donald Davidson has argued, it is only against a background of assumed commonalities that meaningful differences can emerge as 
Published in: Art History Vol. 28 No. 4 (Autumn 2005) pp. 524-51.

differences. ${ }^{20}$ Identification of commensurability or incommensurability is only possible by reference to some tertium comparationis. Ironically, too, the reflexive critique by Bourdieu and others of the ideology of the aesthetic in Western societies, though often mobilised in support of this argument against cross-cultural aesthetics, ultimately ends up confirming their possibility. As a bourgeois ideological projection, aestheticised 'art' does not even exist in Western culture; the appeal to aesthetic judgement is primarily a strategy to disavow the social functions of art, beginning with social stratification of taste. ${ }^{21}$ Most nonWestern societies do not have an aestheticised concept of art, but then, it turns out, neither do Western societies. Such a dismantling of the aesthetic from within thus throws open the possibility of cross-cultural analysis, but on some other basis than that of aesthetic value and meaning.

Gell, Methodological Philistinism and the Anthropology of Art

It is within this context of debate that I wish to discuss the work of Gell. In the anthropology of art Gell has achieved a near cult status, but the details of this thought are little known in other disciplines, and in particular, in art history. This is surprising, for while much of his writing focuses on art in small-scale societies, his interventions into the anthropology of art are informed, in part, by a recurring interest in twentieth-century European art and, in part, by a recurring engagement with art historical literature. His approach to the study of decoration, for example, is highly influenced by Gombrich's The Sense of Order. ${ }^{22}$ 
Published in: Art History Vol. 28 No. 4 (Autumn 2005) pp. 524-51.

A lecturer first at the University of Sussex and then the Australian National University in Sydney, he was, from 1979 until his death in 1997, based at the London School of Economics. He was the author of a number of books - on the anthropology of time, art and ritual in New Guinea, and tattooing in Polynesia - but it is his final two works, Art and Agency (1998) written while he was dying of cancer, and The Art of Anthropology (1999), a posthumous collection of essays, that have had the greatest impact. ${ }^{23}$ It is in these that he comes nearest to devising a systematic anthropological theory of art and accordingly I focus on them.

A distinctive feature of Gell's writing is his critique of traditional anthropology of art for not being anthropological enough. This criticism is directed primarily at the tradition of equating it with the mapping of artworks onto relevant systems of aesthetic values. As Gell notes: 'One of my basic objections to the "cross-cultural aesthetics" and "semiotics" theories of ethnographic art is that the theoretical affinities of these approaches lie in (Western) aesthetics and art theory, not autonomously within anthropology itself. ${ }^{24}$

For Gell, if a theory is to count as an anthropological account of art, it should resemble anthropological discourses on other phenomena, such as religion, kinship, or ritual. This may appear to be rooted in a curious concern with disciplinary propriety, but it underpins a number of important critical points. Indeed, Gell focuses on the ghettoisation of 'ethnographic art' within anthropological discourse, and on the identification of 'ethnographic art' with the object of a museological gaze. This criticism derives from his argument that anthropology should be understood as social anthropology; as such its 
Published in: Art History Vol. 28 No. 4 (Autumn 2005) pp. 524-51.

primary object is the analysis of social relations. The traditional anthropology of art he accuses of being 'essentially geared to refining and expanding the aesthetic sensitivities of the Western art public by providing a cultural context within which non-Western art objects can be assimilated to the categories of Western aesthetic art-appreciation. ${ }^{, 25}$ It is in this context that he calls for 'methodological philistinism,' a turning of attention away from the aesthetic properties of the artwork and towards its role within social relations.

'Philistinism' has come to play an important role in recent polemics against aesthetic theory and value, ${ }^{26}$ but for Gell it denotes the requirement that the anthropology of art adopt the same detachment from its object as the anthropological study of other domains of social practice. Just as the anthropology of religion proceeds on the basis of 'methodological atheism' - i.e. suspense of belief in the religion concerned - so the anthropology of art should withdraw from aestheticism, adopting 'an attitude of resolute indifference towards the aesthetic value of works of art. ${ }^{27}$

For all his protestations regarding disciplinary propriety, Gell's position is influenced here by the anti-aesthetic turn in art criticism. Much of his writing he demonstrates a sustained interest in twentieth-century Western art and, in particular, in Marcel Duchamp, whose work clearly informs many of Gell's criticisms. While anthropology is often still trapped in a nineteenth-century notion of ethnographic art as comprising collectible, aesthetically striking, artefacts (tribal art) amenable to display in the museum, Duchamp had indicated the expanded definitions of art, which Gell himself takes up, nominating the cattle of the Dinka, for example, or hunting traps as art. ${ }^{28}$ 
Published in: Art History Vol. 28 No. 4 (Autumn 2005) pp. 524-51.

In his critique of aestheticism, and in his stress on the role of art in social transactions, Gell's work is influenced by Pierre Bourdieu. ${ }^{29}$ 'Methodological philistinism,' for example, recalls Bourdieu and Darbel's notion of the de-aestheticised, intellectual 'love' of art. ${ }^{30}$ Gell's work, however, focuses on art within micro-social events and relations. This sets him apart from Bourdieu, who highlights the operation of larger scale social structures, institutions and fields. For Gell the aim of the anthropology of art is not to consider indigenous systems governing the evaluation and understanding of art objects, but rather to analyse the function of art as an active participant in social interactions. As Gell states: 'The simplest way to imagine this is to suppose that there could be a species of anthropological theory in which persons or "social agents" are, in certain contexts, substituted for by art objects. ${ }^{, 31}$

The starting point is the concept of enchantment, and the idea of art as a technology of enchantment. These two notions are intended to overcome the traditional opposition between Western (aestheticised) art object and non-Western (functional) artefact. Rather than asserting the irreducible difference between the two, Gell reframes the terms of comparison. At the root of this is an insistence on the 'enchanting' function of the artwork by virtue of the technical efficacy required for its production; both the aesthetic attitude and the attribution of magical and ritual properties to non-Western artefacts are species of technological enchantedness. The artist becomes a kind of occult technician. As a technology of the radical transformation of materials, art attains a kind of 'halo effect' through its sheer complexity; the viewer is awed or baffled when faced with the technical 
Published in: Art History Vol. 28 No. 4 (Autumn 2005) pp. 524-51.

virtuosity of the art object. Gell sees an example in the canoe prows of the Trobriand islanders (Figure 1), and it is the 'halo effect' that functions as the basis of art's social efficacy. It serves to impress or even intimidate the viewer; in his earlier study of Polynesian tattooing Gell writes of its role in seducing others. ${ }^{32}$ Gell thereby expands the idea of technology of enchantment to encompass 'all those technical strategies, especially art, music, dances, rhetoric, gifts etc., which human beings employ in order to secure the acquiescence of other people in their intentions or projects. ${ }^{33}$ As such, it belongs within a taxonomy of technologies that also includes those of production and re-production.

It is tempting to interpret this as a restatement, albeit in an unfamiliar idiom, of a wellestablished argument to do with the role of art in the securing and legitimising of social hegemonies. The idea of the 'halo effect' is reminiscent, for example, of Walter Benjamin's analysis of the role of artistic aura in both maintaining the object's authority and sustaining existing social and class identities. ${ }^{34}$ However, Gell focuses on cultures where, in the absence of the institutionalised aesthetic gaze, enchantment is coded in terms of magical rather than aesthetic experience. Specifically:

... magical technology is the reverse side of productive technology, and ... this magical technology consists of representing the technical domain in enchanted form. If we return to the idea ... that what really characterizes art objects is they way they tend to transcend the technical schemas of the spectator, his normal sense of self-possession, then we can see that there is a convergence between the characteristics of objects produced via the enchanted technology of art and objects 
Published in: Art History Vol. 28 No. 4 (Autumn 2005) pp. 524-51.

produced through the enchanted technology of magic and that, in fact, these categories tend to coincide. ${ }^{35}$

In other words, the technical skill involved in the production of art objects is of an order that leads the viewer to suppose its basis in magic. The speculation that animal traps might be considered as artworks can now be brought into play, but in a transformed manner: the social efficacy of art is founded in its function as a cognitive trap; it seduces and overwhelms the viewer. In Art and Agency this becomes the basis for a reading of apotropaic symbols and images. Rather than warding off evil spirits, such devices entrap them with the same cognitive bafflement as would beset any human viewer. The apotropaic device is a kind of 'demonic flypaper;' by captivating potential demons it renders them harmless, a quality Gell generalises as the 'viscous' quality of all art.

This account appears to aim at describing certain kinds of non-Western cultures, but it is a much wider phenomenon than Gell's apparent interest in the Trobriand Islands would initially indicate. In particular, despite the modernist negation of traditional academic skill, admiration of technical virtuosity still plays a significant part in the response to art objects in contemporary Western cultures. It is observable empirically in popular responses to artists whose work is deemed 'skilful' - from Chuck Close to Andreas Gursky or Jan Vermeer. In addition, the exercise of skill has remained a persistent element in numerous aesthetic and art theories. It even appears in Kant's Critique of the Power of Judgement. For the latter, skill is an intrinsic and necessary, though not sufficient, constituent of genius. $^{36}$ 
Published in: Art History Vol. 28 No. 4 (Autumn 2005) pp. 524-51.

Technological enchantment can be mapped on to the Kantian formulation of the aesthetic experience in other ways, too. Both original and irreducible to routinisation, the product of genius constitutes a cognitive conundrum. The viewer struggles to establish a heuristic that might offer a principle of interpretation, and is compelled to remain within the under- (or over-)determined state of aesthetic judgement. Kant, of course, sees this process as invigorating, as sharpening the cognitive faculties and the interplay between the imagination and the understanding, whereas Gell sees it as destabilising, as a tool in manipulating and gaining control over others. Nevertheless, despite their different evaluations, there are key structural similarities in their accounts. I shall return to the implications of this later, for while enormously suggestive, it also presents potentially serious problems for Gell's declared aim of stripping the anthropology of art of any residual notion of cross-cultural aesthetic appreciation.

Much of Gell's argument is based on a particular reading of ornament, which he describes as 'unfinished business.' It is 'unfinished' inasmuch as the technical, formal and specifically ornamental complexity of the art object exceeds the viewer's ability to organise the visual field. Gell focuses on the presence or absence of redundancy. I use 'redundancy,' following Gregory Bateson, to denote the repetitive and logical pattern that enables one to infer a larger whole from a small interrupted part, and which permits the distinction to be drawn between information and mere noise, between meaning and non-meaning. ${ }^{37}$ Bateson himself uses the notion to interpret the formal and structural hierarchies of Balinese painting, ${ }^{38}$ and it is also taken up by Gombrich in his reading of ornament and decorative 
Published in: Art History Vol. 28 No. 4 (Autumn 2005) pp. 524-51.

art. ${ }^{39}$ Gell's argues that it is through a destabilising of the principle of redundancy that ornamentation can both entrap the cognising subject and also hold them in a kind of cognitive limbo, unsuccessfully trying to construct the framing whole. In other words it presents an analogue, of what Kant describes as aesthetic judgement, inasmuch as the viewer confronts a similar indeterminacy, a similar resistance to the ability to form a logical schema.

So far there is little that might add up to a specifically anthropological theory of art in Gell's understanding of the term. The social dimension is examined in two ways. First, the 'unfinished business' of apotropaic devices, or of ornament in general, their resistance to formal or logical closure, is understood as an analogue of social relations. Gell examines the example of lime containers of the Iatmul of New Guinea (Figure 3). These function as prosthetic extensions of their owners, as objectifications of the person of their owner. What this suggests is highly revealing. First, as decorative schemas that are never exhausted, they communicate the open-ended nature of personhood - it is in some sense incomplete. Second, as mediators of social relations, these and other objects are indicators of the incomplete nature of the social. To quote Gell, 'The essence of exchange, as a binding force, is the delay, or lag, between transactions which, if the exchange relation is to endure, should never result in perfect reciprocation, but always in some renewed, residual, imbalance. So it is with patterns; they slow perception down, or even halt it, so that the decorated object is never fully possessed at all, but is always in the process of becoming possessed. ${ }^{40}$ This is a suggestive analogy, but for Gell it is ultimately less significant than the question of agency. For whether Trobriand magic or Kantian genius, the impact of art 
Published in: Art History Vol. 28 No. 4 (Autumn 2005) pp. 524-51.

depends, to a large measure, on the imputation of a particular kind of agency to the producer.

A number of claims are related to this basic supposition, first of which is the central role accorded to the abduction of agency. 'Abduction' here denotes a specific kind of post hoc inference 'in which a new empirical rule is created to render predictable what would otherwise be mysterious ...,41 The mystery in question is how the cognitively viscous artefacts known as art came into existence. Borrowing from Piercean semiotics, Gell regards the art object as an index - or causal sign - of agency, within a complex of social relations Gell terms the 'art nexus.' This point is crucial, for it marks out Gell's account in that it privileges the index over the other two kinds of sign in Pierce's scheme, the (aesthetic) icon and the (conventional) symbol. ${ }^{42}$

Within the art nexus there are four basic roles - artist, art object (index), prototype (or referent) and recipient - which exist in a variety of permutations depending on whether they are either acting as social agents, i.e. the causal origin of a social transaction, or as 'patients', i.e. the object causally affected by the agent's action. I reproduce the table below (Figure 4). 
Published in: Art History Vol. 28 No. 4 (Autumn 2005) pp. 524-51.

Table I. The Art Nexus

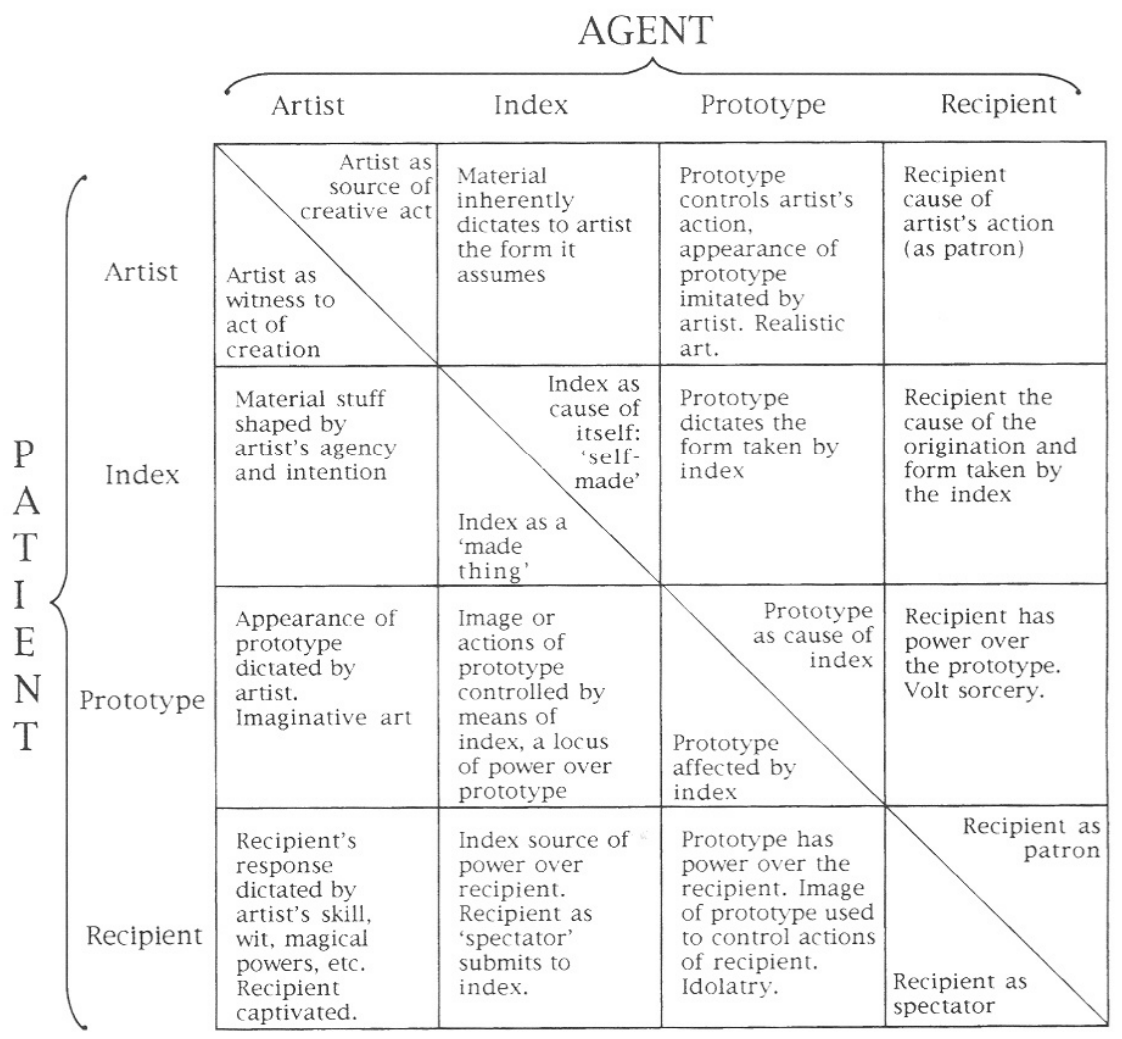

A substantial portion of Art and Agency is devoted to detailing the numerous combinations of agent - patient relations. It also offers complex and convoluted hierarchies of agent patient relations in examples as diverse as nail fetish figures from the Congo (Figure 5) and Mary Richardson's slashing of the Rokeby Venus in 1914. I do not intend to examine these in detail. In broad, however, the theory of the art nexus suggests that while the abduction of agency is central, any one of the four roles can occupy the position of agent and, contrariwise, that of patient. Thus while the art object is most usually deemed to be a patient in relation to the artist, i.e. it is the artist that works and transforms the materials, there are numerous cases in which the index itself becomes an agent, in dictating to the 
Published in: Art History Vol. 28 No. 4 (Autumn 2005) pp. 524-51.

artist, for example, the particular form the work can and cannot take. Gell cites the case of inhabitants of the Antilles who, according to Christopher Columbus, believed that trees dictated to the artist how to shape the trunk into wooden idols. More recent examples, such as the modernist ideology of truth to materials also fall into this category. At another extreme the artist is both the agent and patient within the same event, so-called 'ballistic' behaviour, or 'muscular performances which take place at a rate such that cognitive processing of the "outcome" of action only takes place after the act is complete..., ${ }^{43}$ Within such behaviour - which might be described using Polányi's concept of 'tacit knowledge' the effect of one's own agency is as if that of another. ${ }^{44}$ As Gell notes with reference to the act of drawing: 'Because one's hand is not actually directly controlled by the visualized or anticipated line that one wants to draw, but by some mysterious muscular alchemy which is utterly opaque to introspection, the line which appears on the paper is always something of a surprise. At this point one is a spectator of one's own efforts at drawing; that is, one has become a patient. ${ }^{45}$

The art nexus thus provides a matrix within which both Western and non-Western art can be located as a social practice. What is notable in this account is that the concepts of agency and personhood become radically expanded. Agency is no longer equated solely with the causal nexus surrounding the artist; the recipient, the artwork and the prototype can also function as agents within the art nexus. The notion of the person is also widened by means of the idea of distributed personhood, which Gell derives, in part, from Roy Wagner's notion of the "fractal person. ${ }^{46}$ Art objects function within the social transactions of the art nexus because they are treated not merely as social agents but as persons, and this stems 
Published in: Art History Vol. 28 No. 4 (Autumn 2005) pp. 524-51.

from the fact that as indexes of the agency of the artist, recipient, or prototype, they constitute an extension of that person. Personhood is dispersed through the indexical signs of its efficacy as a social agent. This also echoes an argument put forward in his analysis of tattoos, drawing attention to their role in the multiplication of social personhood;

The basic schema of tattooing is thus definable as the exteriorization of the interior which is simultaneously the interiorization of the exterior. One can understand this as a process of involution, the creation of an extra layer by folding the skin over upon itself ... This double skin, folded over on itself, creates the possibility of an endless elaboration of interacting components of the social person. The body multiplies; additional organs and subsidiary selves are created; spirits, ancestors, rulers and victims take up residence in an integument which begins to take on a life of its own. ${ }^{47}$

Gell is thereby also attempting to circumvent the tendency, within Western social theory, to focus on the problematic relation between individual subject and social totality. With the notion of 'distributed personhood,' the person as social agent is always already dispersed and multiple. Examining the case of genealogical idols from the Cook Islands, Gell notes: "Any individual person is "multiple" in the sense of being the precipitate of a multitude of genealogical relationships, each of which is instantiated in his/her person; and conversely, an aggregate of persons, such as a lineage or tribe, is "one person" in consequence of being one genealogy. ${ }^{48}$ And citing Wagner he adds: 'A fractal person is never a unit standing in relation to an aggregate, or an aggregate standing relation to a unit, but always an entity with relationship integrally implied. Perhaps the most concrete illustration of integral 
Published in: Art History Vol. 28 No. 4 (Autumn 2005) pp. 524-51.

relationship comes from the generalised notion of reproduction and genealogy. People exist reproductively by being "carried" as part of another, and "carry" or engender others by making themselves genealogical or reproductive" factors" of these others. A genealogy is thus an enchainment of people ... ${ }^{49}$ The example of genealogy is perhaps unconvincingit underplays the extent to which genealogies can become fixed social institutions - but the overall thrust of the argument merits serious attention. Its aim is to retain the notion of agency, not by trying to defend a residual notion of subjectivity from the numerous antihumanist critiques levelled at it, but by rethinking the concepts of agency and personhood. Agency can be retained if one ceases to equate it with humanist notions of the human subject.

\section{Critical Issues}

Gell has not been without his detractors. Critics have identified a number of important weaknesses in Gell's book. These include: an overestimation of the importance of decorative art (and a concomitant underplaying of the role of figurative representations); a naïve use of ethnographic evidence; a lack of a coherent account of aesthetic value; an unnecessary exclusion of iconic and symbolic meaning. ${ }^{50}$ Art and Agency is also open to charges of inconsistency, for Gell engages in a lengthy discussion of that most aesthetic of anthropological categories: style, having begun with a call for the exclusion of such concepts. 
Published in: Art History Vol. 28 No. 4 (Autumn 2005) pp. 524-51.

While, in Gell's defence, one should highlight that Art and Agency is a first draft - it was written over a period of just three weeks - these are important weaknesses. In particular, the attention to style is inconsistent with his general position, although this is not fatal to his account, for the theory of the art nexus makes no reference to style. The issue of decorative art is perhaps more important, but as I suggest below, the concept of enchantment might be refigured in a way that mitigates this limitation. Furthermore, since the art nexus is a metalevel concept, it can be defended against the criticism of the lack of interest in aesthetic values, for it designates a structure that encompasses both aesthetical and magical transactions. Yet Gell's work has other weaknesses, too. Consequently, before considering its positive implications it is necessary to explore some of the difficulties it presents, in order to reconstruct it in a more viable form.

The theory of the art nexus suggests that cross-cultural analysis is possible, but at the cost of giving up traditional frames of analysis. Indeed, it suggests that analysis of the art of non-Western cultures also entails a relinquishing of traditional schemata for the understanding of Western art. At the same time, it arguably fails to break free entirely from the hold of aesthetics. As a technology of enchantment, the captivating power of art stems from its display of technical efficacy and skill. This account has a suspiciously aesthetic and formalist character; the theory of enchantment could easily be equated with that of the sublime which, from Kant onwards, has been seen as definitive of the experience of artworks. ${ }^{51}$ Technological captivation would thus be the enactment of an ethnographic sublime. 
Published in: Art History Vol. 28 No. 4 (Autumn 2005) pp. 524-51.

Gell might be defended against this charge in two ways, perhaps. First, while there is an apparent parallel with Kantian and post-Kantian theories of the aesthetic, the theory of technological enchantment is aimed less at elaborating a specific kind of experience indeed it could be regarded as under-theorised in his description - than at the analysis of the social function of such a captivation through art. In this respect, while from one perspective is stands comparison with formalist aesthetic notions, it also bears a more than passing resemblance to Althusserian notions of interpellation. ${ }^{52}$ Few would see in Althusserian theories of image response a revival of Kantian themes, and hence Gell's account of enchantment might be 'de-aestheticised' if seen in these terms. Gell is not specifically interested in ideology as a category of analysis, nor in the specific notion of subject formation that is an intrinsic part of the concept of interpellation; his adoption of the theory of 'distributed personhood' clearly distinguishes his account from Althusserian theories. Nor is he concerned with the institutional structures of modern societies that motivate Althusser. Nevertheless, the theory of interpellation does at least suggest that 'enchantment' need not be thought of as an aesthetic category. Indeed, Gell's work can also be freed of Kantian echoes if it is recalled that the concept of redundancy, while employed by Gombrich in relation to ornamental art, originates in communication theory and is primarily intended to account for the logic of communication and meaning. Thus, for Bateson, redundancy is virtually identical with meaning: 'I would argue that the concept of "redundancy" is at least a partial synonym for "meaning." As I see it, if the receiver can guess at missing parts of the message, then those parts which are received must, in fact, carry a meaning which refers to the missing parts and is information about those parts. ${ }^{, 53}$ One might now demur at Bateson's equation of communication with the simple 
Published in: Art History Vol. 28 No. 4 (Autumn 2005) pp. 524-51.

transmission and receipt of 'information' - current communication theory would dispute this view - but the crucial point here is that redundancy is not simply a matter of aesthetic pattern recognition, but of interpretation in general. ${ }^{54}$

It is still necessary to address the disproportionate role accorded to decoration and ornamentation in Gell's writing. It is clear that this is motivated by the ornamental nature of the kind of art Gell takes as his primary material - despite his strictures against the ghettoisation of 'ethnographic' art. Yet if the notion of enchantment is extended in the way suggested by the concept of interpellation, the tie to the limited domain of ornamental art is dissolved. This does present problems for the reliance on redundancy as a key determinant of enchantedness, but this is in keeping with Gell's emphasis on the role of the art nexus as a whole, and of the complex relations between the social actors involved. In the case of many art forms captivation can be seen as an effect of certain agent - patient relations. In societies where agency is lodged with the artist, admiration of technical skill is a prime component of enchantedness, but in others, where agency is lodged with, for example, the prototype, enchantedness has a quite different root. As Hans Belting has argued in regard to medieval and Byzantine icons, a similar conception was held for much of the post-classical era:

Every image, no matter of what kind, originated in a prototype, in which it was contained in essence (by dynamis) from the outset. As an impression belonged to a seal and a shadow or a reflection to a body, so a likeness belonged to a model. The image was thereby taken away from the caprice of the painter and related to its 
Published in: Art History Vol. 28 No. 4 (Autumn 2005) pp. 524-51.

archetype. By adopting the essence of the archetype, the image borrowed the supernatural power that justified its worship. ${ }^{55}$

This notion underlay both the cult of images and the vehemence of the iconoclasts' campaign against icons. Michael Camille has summarised this situation succinctly: 'to want to destroy a false image one had to believe in its evil efficacy, its power over self as well as over the Other. ${ }^{56}$

Some of these issues have been explored by Suzanne Küchler in relation to knots in Tahiti, Hawaii and New Ireland. ${ }^{57}$ Given Gell's recurrent use of metaphors of ensnaring and binding, the knot is a particularly useful subject of analysis, most especially since Celtic knot work is mentioned in Art and Agency as an example of the technology of enchantment. As a 'knowledge technology' knots are, for Küchler, 'responsible for externalising nonspatial logical problems in a distinctly spatial manner. ${ }^{58}$ The knot is a metaphor for the complex social bonds in certain societies and in Hawaii knot-weaving traditionally played a key role in the installation of the king and during his subsequent reign. It symbolised the role of the king as a 'braider' of the social strands of society. Moreover, not only did the knot symbolise the social relations between the kind and his subjects, it also perpetuated them. As Küchler argues, 'The capacity of the knot to fashion a decentred spatial cognition is of paramount importance for understanding how knotted effigies can visually and conceptually effect a "body politic" that appears once phenomenal and yet also mystical in nature. ${ }^{59}$ The geometrical and topological complexity of the knot confirms the mystery of kingship, suggesting an intertwining of the phenomenal, visible, figure of the king and the 
Published in: Art History Vol. 28 No. 4 (Autumn 2005) pp. 524-51.

invisible divine powers flowing through the office of the monarch. In a manner parallel to the image cult of Byzantium, the complexity of the knot is not simply due to the skill of the braider, but rather stems from its function as an index of its divine prototype.

It is also necessary to address the objection that technical complexity has seldom been the prime source for the social efficacy of artworks; as Ross Bowden has pointed out in criticism of Gell, there are numerous cases where the technical virtuosity of artists has been celebrated, while their conceptual and aesthetic originality remained in question. ${ }^{60}$ Aesthetic admiration can never be based on technical brilliance alone, yet much depends on the definition of technical virtuosity. Bowden limits 'skill' to purely technical accomplishment, but it can be expanded. For by 'skill' is meant both purely technical accomplishments and also those higher levels qualities of aesthetic and conceptual originality.

Yet, if the role Gell accords to skill and technique can be defended, other questions still remain. Central to these is the definition of 'art.' Partly in order to side-step the issue of aesthetics, and partly also because of his suspicions of the museographical gaze, Gell brackets out the question of what art might be. Indeed, he argues that 'art' is anything that functions as an index of social agency within the 'art nexus,' and as I have noted before, he is critical of scholars working in the field for their limited association of 'art' with 'artefacts.' 
Published in: Art History Vol. 28 No. 4 (Autumn 2005) pp. 524-51.

Gell's anti-essentialism clearly aligns his anthropology of art with parallel notions in the field of art theory and criticism and, in particular, institutional theories of art. ${ }^{61}$ Like those theories, too, it arguably restates the problem at a higher level. Instead of questions about the specificity of the art object, the debate now moves on to consideration of how the 'art nexus' is distinguishable from other matrices of social interaction. The clearest response is to argue that the 'art nexus' constitutes a matrix within which social relations and interaction are mediated by artefacts, whether 'museographic' artefacts, or phenomena of nature. However, there are many other instances of objects functioning as extensions of social agents, and as crucial mediators of social interaction, without them being considered works of art. Economic relationships and interactions, for example, revolve entirely around mediating artefacts and symbols. However, the question is then raised as to how such interactions are mediated, and here the 'art nexus' is distinguished by virtue of the central role of enchantment, which holds together the four functions of agency, patient, recipient and index; this quadripolar matrix of social relations is not replicated in other kinds of social interaction.

Gell's theory should thus not be seen as depending on any single factor - artwork, enchantment, art nexus - but on the interplay between them. Moreover the question as to specificity of the art nexus is not quite parallel to that of art and the aesthetic. The art nexus is a meta-concept; some 'art' transactions will be coded as aesthetic, some as magical and others as religious and so forth.This might be amplified by reference to Gell's response to a well known study by the British anthropologist Jeremy Coote on the cattle of the Dinka of the Sudan (Figure 5). ${ }^{62}$ Where Coote had stressed the significance of cattle as a measure of 
Published in: Art History Vol. 28 No. 4 (Autumn 2005) pp. 524-51.

the aesthetic preferences of the Dinka - and hence of a Dinka 'aesthetics' - Gell stressed the intertwining of 'aesthetic' values and other social factors - in particular, the competition for prestige amongst the young male cattle-herders of the Dinka. For Gell one cannot identify a specific aesthetic system without artificially separating it from the larger transactional nexus to which it belongs.

\section{An Art Historical Discourse?}

Up to this point I have considered Gell's work primarily in relation to the traditional subject matter of the anthropology of art, namely, art in small-scale societies. It is timely, therefore, to turn to the broader applicability of Gell's work, and to consider the gains accruing from such an application. It is especially pertinent in that his critique of traditional anthropological aesthetics is in part motivated by the concern to introduce as elastic a notion of artwork as that operating within Western art criticism, commensurate with the practices of $20^{\text {th }}$ century modernism and the avant-garde. In addition, following Gell's acknowledged debt to Bourdieu, the theory of the art nexus parallels the numerous calls for a reorientation of art history towards analysis of the ideological and institutional frame of art at the expense of traditional concerns with individual artworks. ${ }^{63}$ Yet while there are clear affinities between the calls for an end to 'traditional' art theory and the critique of anthropological aesthetics, it is important to recognise their differences. Where, in the wake of writers such as T. J. Clark, Victor Burgin or Craig Owens, art history and theory have turned increasingly to art as a social institution, Gell's work focuses on micro-social interactions involving the art nexus. His work is both narrower in focus and, paradoxically, 
Published in: Art History Vol. 28 No. 4 (Autumn 2005) pp. 524-51.

potentially wider in application; while the art nexus was developed to account for a range of phenomena within the traditional domain of the anthropology of art, it can be seen as providing a meta-discourse that illuminates various issues in art practice and theory in Western societies. In the remainder of this article I explore a few cases.

An instructive example can be seen in theories of the historicity of representation. In his account of the viewing of artworks - the phenomenon of enchantment - Gell is partly informed by David Freedberg's wide-ranging study of image response, The Power of Images. ${ }^{64}$ Freedberg's work is a rich source of historical information about changing patterns of image response and it can be located alongside a growing body of scholarship on image reception, from the theoretical work of Wolfgang Kemp to that of Belting mentioned earlier. ${ }^{65}$ Key to his account of image response is the analysis of the interrelation of image response and image theory. The auratic power of images is directly founded in their function not merely in depicting the subject, but in making the subject copresent with the image.

Freedberg's book offers a timely reminder of the intertwining of image response and theory - in a study which points both to the mutability of the response to art, and also to the historical and cultural specificity of aesthetic experience. At the same time, however, it is open to methodological critique, for it is arguably rooted in outmoded nineteenth-century anthropological notions of art. Specifically, it sees pre-modern art in magical and cultic terms, positing a caesura between modernity and the pre-modern in terms of the break from cultic ritual. According to this account, image responses that evoke cultic practices are 
Published in: Art History Vol. 28 No. 4 (Autumn 2005) pp. 524-51.

relics or survivals of an earlier stage in cultural development. In such accounts art is connected with magic, which is seen as operative in ('primitive') technologically underdeveloped societies. Within anthropology such an opposition of modern technology and primitive magic has long been disputed, but as Freedberg's book indicates, it has been central to writing on art. ${ }^{66}$ It is evident, for example, in Walter Benjamin's discussion of technological reproduction, whose positing of a cultic origin to art remains one of the least questioned claims of the entire essay. ${ }^{67}$ One can go back a little further and see a reflex of such a notion in the writings of Aby Warburg and Julius von Schlosser. For Warburg the history of representation could be mapped by tracing the oscillations between a regression to primitive cultic violence, on the other hand, and a rationalising modernising impulse on the other. A primitive cultural unconscious thus always lay close to the surface of Western modernity ${ }^{68}$ Schlosser drew on a similar conceptual schema in his study of the history of wax effigies; for Schlosser the persistence of wax portraiture into the $19^{\text {th }}$ century, with the extraordinary mimetic properties of the image suggesting not merely a representation of the sitter but their actual presence, was evidence of the survival of a primitive inability to distinguish between the real and its representation. ${ }^{69}$ Schlosser thus argues that the extreme realism of the wax portrait was linked to a belief in the demonic and magical inhabitant of the image.

According to this account there is an absolute difference between the primitive cult of the image-as-presence and the modern notion of image-as-representation. The shift from one to the other occurred, for Schlosser, with the rise of neo-classical aesthetics in the $18^{\text {th }}$ century. In his study of the image cult Belting locates the shift occurred in the early $16^{\text {th }}$ 
Published in: Art History Vol. 28 No. 4 (Autumn 2005) pp. 524-51.

century, but a similar framework holds: any practice or discourse that stands between is cast as an intermediate stage, or as a 'survival' of earlier magical, cultic practices - a term often employed in Victorian anthropology. Echoes of such a notion can also be detected in Michel Foucault's work on the history of truth regimes. Although there is no talk of relics, survivals or magical cults, Foucault's tracing of the shift from the Renaissance regime of representation based on resemblance to the metonymic régime of the Classic Age posits an absolute difference between two heterogeneous and incommensurable representational systems. $^{70}$

The work of Gell suggests an alternative means of conceptualising this phenomenon. The theory of the art nexus posits a reconfiguration of relationships, and in particular, a shift from a theory in which, following Gell's terminology, agency is no longer exercised by the prototype but rather by the artist. Of course the shift may be coded in terms of the waning of magic and its displacement by agnostic humanist notions of creativity, but to see in this a deeper cognitive or representational shift is to underplay the extent to which other relations within the art nexus, between, for example, recipient and index, or between index and recipient, may well remain the same. It also overestimates the significance of one particular shift when, arguably, equally significant shifts in the art nexus have occurred since; during the twentieth century one recurrent aesthetic ideology, the formalist doctrine of 'truth to materials,' shifted agency away from the artist to the index. One could add to this consideration of the role of the recipient as agent. Though couched in an unfamiliar terminology, the idea of the recipient as agent is familiar to traditional art historical discourse; the numerous studies of patronage offer ample testimony to this. While in some 
Published in: Art History Vol. 28 No. 4 (Autumn 2005) pp. 524-51.

cases patronage is seen simply as a mediating factor in the production of art, in others the patron is seen as the primary cause of the art, determining the content, iconological programme and the material and formal basis of artworks, alongside dominant styles and taste. Moreover, if the recipient can be seen in terms of the role of the patron, it can also be considered in terms of the spectator. One might mention here not only Roland Barthes' widely recognised theoretical claim concerning the constitutive role of the reader / viewer in the formation of artistic meaning, but also the numerous historical practices, from the performances of Marina Abramović and Yoko Ono to the compositions of Karlheinz Stockhausen of Luciano Berio - open works in Eco's formulation - which actively solicit the involvement of the audience such that the latter becomes both the patient and the agent of its completion. ${ }^{71}$

The shifting functions of agency can also be seen when considering the figure of the artist, which has enjoyed a complex relation to the question of the agent. At one extreme it is evident, from the Homeric invocation of the muse in the opening lines of the Iliad and the Odyssey, that the author figure was, according to an early Greek tradition, a conduit for the telling of mythic narrative, rather than its originator or instigating agent. In the terms of the art nexus one might state that the Homeric poet is a patient, with agency exercised either by the prototype - the mythic world - or by the index - the narrative tells itself through the muse. In this sense artistry is immersed in a mythic world of extra-human powers and agents which, in the schema of Victorian anthropology, would have confirmed the rootedness of Greek art in more ancient primitive cultic practice. Such a conclusion was indeed reached by figures such as Nietzsche, Jane Harrison or Aby Warburg. ${ }^{72}$ Yet this 
Published in: Art History Vol. 28 No. 4 (Autumn 2005) pp. 524-51.

notion was also accompanied by a mythology of the artist as an occult technician. Both in the Homeric poems - in the accomplishments of the god Hephaistos - and more generally, too, in figures such as that of Daidalos, the artist is a kind of magician wielding extraordinary skills and capacities. ${ }^{73}$ Clearly an important shift has occurred, in which agency has been transferred to the artist from the prototype or the index. And this can be seen as continuing into classical times where the extraordinarily illusionary effects of the paintings of Apollodorus or Zeuxis are no longer attributed to magic but to technical skill. ${ }^{74}$

The obvious question to ask is: what difference it makes to frame authorial agency in these terms. In response it is important to note, first, that there are competing readings of this shift. One reading has drawn on such myths to foreground the magical origins of $\operatorname{art}^{75}$ For this interpretation the idea of the artist as magician is a continuation of the notion of art as the voice of other occult forces - Homeric muses - and is structurally linked to the magical and cultic identification of the image with its subject. The later heroisation of the artist in classical times and Renaissance Humanism can thus be seen as a survival of such magical conceptions. A similar notion appears in Barthes' famous thesis on authorship, which posits humanist notions of the author as theological in origin. ${ }^{76}$ From the perspective of the theory of the art nexus, the fact that the production of art is coded in magical or technological terms is not as significant as the changing relations of the four factors - artist, index, prototype and recipient - in the nexus.

This helps rethink certain debates concerning the ideological function of art. According to a well established argument, one of the ideological effects of art lies in its ability to mask the 
Published in: Art History Vol. 28 No. 4 (Autumn 2005) pp. 524-51.

labour of production, naturalising the image, for example, as a window onto the visible. ${ }^{77}$ This also provides the basis, according to this argument, for the ideological underpinning of the Western mimetic tradition and, in particular, its amenability to employment as an instrument for legitimising cultural and social hegemony.

It is undoubtedly the case that certain kinds of art practice foreground the process of production - the fauvist paintings of Matisse, Derain or Vlaminck, the films of Andy Warhol - while others minimise it. But to attribute this ideological function to the image alone relies on a problematic fetishism of the artwork. A key role is also played by the location of agency. In a culture where the primary agent is held to be the prototype or the recipient, the 'naturalising' function of the mimetic artwork will differ from cases where agency is located in the artist. In the case of the latter, although the artist's skills in, for example, depicting their subject 'realistically,' are admired, it is by no means apparent that the work is then seen as an ahistorical window onto the visible world. The effect of the real is as much a consequence of the recognition of the labour of production as of a masking of it; the agency of van Eyck (Figure 6) or Ingres - their mimetic skill - is as much in evidence as the reflexive foregrounding of the labour of production by, for example, Velasquez or Kirchner (Figure 7). Western illusionism is not as powerful an ideological instrument as is often supposed. Arguably art, as a technology of enchantment, captivates one might even say 'interpellates' - the viewer not by masking the labour, but by displaying it. 
Published in: Art History Vol. 28 No. 4 (Autumn 2005) pp. 524-51.

An equally significant consequence of Gell's theory stems from its ability to intervene in debate on the question of authorship. Specifically, the critique of the author, from Barthes and Foucault onwards, has tended to conflate authorship with agency. Recognition of the problematic status of humanistic notions of authorship led not merely to a questioning of a particular conception of subjectivity but to an erasure of agency per se. The flaws in the proposed solutions, in particular, Barthes' theoretically contradictory and incoherent advocacy of the reader and inter-textuality, hardly need stating. ${ }^{78}$ Michael Baxandall has, of course, indicated possible means of retaining a commitment to the notion of art as an intentional activity without acceding to humanist notions of the kind critiqued by Barthes, Foucault and others. ${ }^{79}$ Gell offers another framework for describing agency, making it a broader concept than the simple ascription of intention to subjects. His description of 'ballistic behaviour' noted above can be adduced in this context. 'Ballistic behaviour' denotes the process where the artist stands in the position of both patient and agent in the art nexus. Gell discusses this phenomenon in physiological terms, but it can also be used as a means of conceptualising certain conceptions of artistic production. Most immediately the ideology of automatism replicates exactly this phenomenon, but so too does Vasari's recommendation that 'the best thing is to draw men and women from the nude and thus fix in the memory by constant exercise the muscles of the torso, back, legs and knees, with the bones underneath. ${ }^{80}$ In other words, through routinisation, one is an agent without conscious intention.

\section{Conclusion}


Published in: Art History Vol. 28 No. 4 (Autumn 2005) pp. 524-51.

I began this discussion with the problematics of cultural difference, and in particular, the difficulties involved in the application of Western art discourses to the understanding of non-Western art. The weaknesses of certain aestheticising and historicising practices have led to the positing of an absolute non-commensurability. As even an initial consideration of Gell might suggest, there are other frameworks of analysis that can overcome this conceptual impasse. Although formulated in response to specific debates in anthropology, Gell's attempt to analyse art as an actor in the formation of social relations can clearly be mapped on to the terrain of Western art. In addition, it poses significant questions to certain methodological assumptions sustaining current social theories of Western art. It also presents a schema for the cross-cultural analysis of art that begins to lay out the grounds for the identification of some sort of commensurability. Nevertheless, various observations remain.

The theory of the art nexus operates at a level of abstraction and taxonomic codification that presents difficulties for the analysis of concrete practices. What it also suggests, however, is the compromise necessary to maintain any cross-cultural discourse; commensurability emerges through an attaining of distance while, correlatively, immersion in a cultural practice will tend to confirm the idea of non-commensurability. The key issue concerns the question as to whether the abstraction involved in the theory of the art nexus involves such a level of generality as to render it problematic as a tool of analysis. While it operates at a certain level of generalised abstraction, this is arguably much less than was the case with Summers or Anderson mentioned earlier; indeed, it is no more so than the "high 
Published in: Art History Vol. 28 No. 4 (Autumn 2005) pp. 524-51.

theory' of Foucault, post-structuralism or deconstruction, all of which have been of enormous recent significance for the analysis of art.

The second issue is that of interdisciplinarity. Within art history the espousal of interdisciplinarity has a long tradition. As early as 1894 Ernst Grosse claimed that 'the most immediate and pressing task for the social history of art is the investigation of primitive art, ${ }^{, 81}$ while Aby Warburg conducted his celebrated ethnographical study of the Pueblo Indians in 1896 . However, such notions have often been limited to the adoption of a value system that privileges alterity, rather than involving a proper engagement with the methods of other disciplines. Taking the work of Gell seriously implies a deeper level of disciplinary engagement, which involves not merely the adoption of a different set of values but also a different methodological framework that would lead to a transformation of art historical practice.

Third, Gell's work was motivated by a concern to maintain and fortify a disciplinary boundary, namely, that of anthropology. Yet despite that original motivation it is clear that a properly anthropological theory of art - in Gell's sense of the term - is of potentially enormous consequence for other discourses on the subject. Pace Gell, the theory of the art nexus needs to be taken out of the 'ghetto' of anthropology. Fourth, and finally, the art nexus is undoubtedly a Western representational apparatus. Yet its distance from the specificities of Western art practices gives it a cross-cultural currency that other aesthetic theories cannot claim to possess. As an apparatus of Western academic discourse it is ultimately still vulnerable to the familiar accusation of imposing occidental logical 
Published in: Art History Vol. 28 No. 4 (Autumn 2005) pp. 524-51.

schemata on other cultures. Nevertheless, it makes an important intervention into the debate as to the kinds of questions that might be posed and opens up discussion to new possibilities.

${ }^{1}$ On such universal histories see Dan Karlholm, Handböckernas konsthistoria: Om Skapandet av “Allmän Konsthistoria” I Tyskland under 1800-Talet, Stockholm, 1996;

Carol Doyon, Les Histoires Générales de l'Art, Laval, 1991.

${ }^{2}$ An obvious example might be Hugh Honour and Peter Fleming's A World History of Art, London, 1982.

${ }^{3}$ Ernst Gombrich, The Story of Art, London, 1950. On the critique of Hegel see Gombrich, 'In Search of Cultural History,' in Ideals and Idols, London, 1979, 24-59, and 'The Father of Art History: A Reading of the Lectures on Aesthetics of G. W. F. Hegel (1770-1831),' in Tributes. Interpreters of Our Cultural Tradition, Oxford, 1984, 51-70.

${ }^{4}$ This was evident both in early survey texts, such as Münsterberg’s 1908 study and also in later ones such as Kidder's The Art of Japan (1984). See Oskar Münsterberg, Japans Kunst, Braunschweig. 1908; Edward Kidder, Jr., The Art of Japan, Milan, 1984.

${ }^{5}$ An exception to this tendency can be found in Bonnie Wade, Imaging Sound. An Ethnomusicological Study of Music, Art, and Culture in Mughal India, Chicago, 1998. Wade explores the role of music and the representation of music in the courts of the Mughal rulers.

${ }^{6}$ See the Abbé Batteux, Les Beaux Arts Réduits à un Même Principe, Paris, 1747. More generally, see Larry Shiner, The Invention of Art, Chicago, 2001. 
Published in: Art History Vol. 28 No. 4 (Autumn 2005) pp. 524-51.

${ }^{7}$ See, for example, Pierre Bourdieu, Distinction, Cambridge, 1986, and Terry Eagleton, The Ideology of the Aesthetic, Oxford, 1990. See, too, the contributions of Joanna Overing and Peter Gow to the debate 'Aesthetics is a Cross-Cultural Category,' in Tim Ingold, ed., Key Debates in Anthropology, London, 1996, 260-66 and 271-75. There have been dissenting voices. See, for example, Noel Carroll, Beyond Aesthetics, Cambridge, 2001, and, more recently, Paul Crowther, 'Defining Art, Defending the Canon, Contesting Culture,' in British Journal of Aesthetics, 44.4, 2004, 361-77.

${ }^{8}$ See, for example, Clifford Geertz, 'Art as a Cultural System,' in Geertz, Local Knowledge, London, 94-120.

${ }^{9}$ James Elkins, Stories of Art, London, 2003. See, too, 'Why It is Not Possible to Write the Art History of Non-Western Countries,' in Jan Bakoš, ed., Minulost'v Pritomnosti:

Súčasné Umenie a Umeleckohistorické Myty, Bratislava, 2003, 229-55.

${ }^{10}$ See, for example, Quintilian's history of Greek sculpture (Institutio Oratoria, 12.10.110) in J. Pollitt, ed., The Art of Ancient Greece. Sources and Documents, Cambridge, Cambridge, 1990, 221-23.

${ }^{11}$ Qādī Ahmad, Calligraphers and Painters, trans. V. Minorsky, Washington, 1959.

${ }^{12}$ I note 'erroneously' since the privileging of cultural alterity should not be equated with ethnography per se. Debates over the cross-cultural applicability of 'art' and 'aesthetic experience' have taken place within ethnography and anthropology in the same way that they have in philosophy, cultural studies and art history.

${ }^{13}$ See Craig Clunas, Pictures and Visuality in Early Modern China, London, 1997.

${ }^{14}$ On the comparative study with Japan see 'Comparisons and Conclusions,' in Peter Burke, The Italian Renaissance. Culture and Society in Italy, Cambridge, 1986, 248-56. On 
Published in: Art History Vol. 28 No. 4 (Autumn 2005) pp. 524-51.

the profession of painting in China see James Cahill, The Painter's Practice. How Artists Lived and Worked in Traditional China, New York, 1994.

${ }^{15}$ See, for example, Timon Screech, The Shogun's Painted Culture. Fear and Creativity in the Japanese States 1760-1829, London, 2000.

${ }^{16}$ Richard Anderson, Calliope's Sisters. A Comparative Study of Philosophies of Art, London, 1990.

${ }^{17}$ Anderson, Calliope's Sisters, 241.

${ }^{18}$ David Summers, Real Spaces. World Art History and the Rise of Western Modernism, London, 2003.

${ }^{19}$ Similar points have been made by James Elkins, Review of David Summers, Real Spaces,' in Art Bulletin, 86.2, 2003, 232-37.

${ }^{20}$ Donald Davidson, 'On the Very Idea of a Conceptual Scheme,' in Davidson, Essays on Truth and Interpretation, Oxford, 1984, 183-98.

${ }^{21}$ See Pierre Bourdieu, Distinction.

${ }^{22}$ An account of Gell's intellectual development and career can be found in Alan Macfarlane, 'Alfred Gell (1945-1997),' in Proceedings of the British Academy, 120, 2003, $123-47$.

${ }^{23}$ Alfred Gell, Metamorphoses of the Cassowaries. Umeda Society, Language and Ritual, London, 1975; The Anthropology of Time. Cultural Constructions of Temporal Maps and Images, Oxford, 1992; Wrapping in Images: Tattooing in Polynesia, Oxford, 1993; Art and Agency, Oxford, 1998; The Art of Anthropology. Essays and Diagrams, ed. Eric Hirsch, London, 1999.

${ }^{24}$ Gell, Art and Agency, 9. 
Published in: Art History Vol. 28 No. 4 (Autumn 2005) pp. 524-51.

${ }^{25}$ Art and Agency, 3.

${ }^{26}$ See David Beech and John Roberts, eds., The Philistine Controversy, London, 2003.

${ }^{27}$ The Art of Anthropology, 161.

${ }^{28}$ See Gell, 'Vogel's Net: Traps as Artworks and Artworks as Traps,' in The Art of Anthropology, 187-214.

${ }^{29}$ Gell himself admitted this in the autobiographical introduction to The Art of Anthropology. 'Only on the surface am I a Bourdieu critic. Actually, I read Bourdieu obsessively and with unstinted admiration for his dialectical skill,' Gell, The Art of Anthropology, 8.

${ }^{30}$ Pierre Bourdieu and Alain Darbel, The Love of Art, Cambridge, 1997.

${ }^{31}$ Art and Agency, 5.

32 'Marked, patterned or scarred skin draws in the gaze of the onlooker, exercises the power of fascination and lowers certain defences. The eye isolates and follows the mazy pathways of the design and eventually, so to speak, enters the body of the others, because the peculiarity of tattooing is that it is inside the skin rather than on its surface. Thus to view a tattoo is to be in a position of seduction ...' Gell, Wrapping in Images, 36.

${ }^{33}$ Gell, 'Technology and Magic,' in Jonathan Benthall, ed., The Best of “Anthropology Today”, London, 2002, 282.

${ }^{34}$ Walter Benjamin, 'The Work of Art in the Age of its Technical Reproducibility' $\left(2^{\text {nd }}\right.$ version), in Benjamin, Selected Writings Volume 3: 1935-1938, Cambridge, Mass, 2002, 101-33.

${ }^{35}$ Gell, The Art of Anthropology, 181. 
Published in: Art History Vol. 28 No. 4 (Autumn 2005) pp. 524-51.

${ }^{36}$ Immanuel Kant, Critique of the Power of Judgement, trans. Paul Guyer and Eric

Matthews, Cambridge, $\S \S 46-47$.

${ }^{37}$ Gregory Bateson, 'Redundancy and Coding,' in Steps to an Ecology of Mind, Chicago, $2000,416-31$.

${ }^{38}$ Bateson, 'Style, Grace and Information in Primitive Art,' in Steps to an Ecology of Mind, 101-25. See, especially, $120 \mathrm{ff}$.

${ }^{39}$ Sir Ernst Gombrich, The Sense of Order. A Study in the Psychology of Decorative Art, London, 1979.

${ }^{40}$ Gell, Art and Agency, 81 .

${ }^{41}$ Gell, Art and Agency, 14.

${ }^{42}$ A detailed discussion of this issue can be found in Karel Arnaut, 'A Pragmatic Impulse in the Anthropology of Art? Alfred Gell and the Semiotics of Social Objects,' in Journal des Africanistes, 71.2, 2001, 191-208.

${ }^{43}$ Gell, Art and Agency, 45.

${ }^{44}$ Michael Polányi, The Tacit Dimension, New York, 1966.

${ }^{45}$ Gell, Art and Agency, 45.

${ }^{46}$ Roy Wagner, 'The Fractal Person,' in M. Strathern and M. Godelier, eds., Big Men and Great Men: Personifications of Power in Melanesia, Cambridge, 1991, 159-73.

${ }^{47}$ Gell, Wrapping in Images, 39.

${ }^{48}$ Gell, Art and Agency, 140.

${ }^{49}$ Gell, Art and Agency, 140.

${ }^{50}$ See, for example, Ross Bowden, 'A Critique of Alfred Gell on Art and Agency,' in Oceania, 70.4, 2004, 309-28. 
Published in: Art History Vol. 28 No. 4 (Autumn 2005) pp. 524-51.

${ }^{51}$ This connection has recently been reinforced by Kirk Pillow in relation to Kant and Hegel. See Pillow, Sublime Understanding. Aesthetic Reflection in Kant and Hegel, Cambridge, Mass, 2000.

${ }^{52}$ Louis Althusser, 'Ideology and Ideological State Apparatuses,' in Lenin and Philosophy, London, 1971, 127-88.

${ }^{53}$ Bateson, Steps to an Ecology of Mind, 420.

${ }^{54}$ For a critical reading of this model see Briankle Chang, Deconstructing Communication: Representation, Subject, and Economies of Exchange, Minneapolis, 1996.

${ }^{55}$ Hans Belting, Likeness and Presence. A History of the Image before the Era of Art, trans. Edmund Jephcott, Chicago, 1994, 153.

${ }^{56}$ Michael Camille, The Gothic Idol. Ideology and Image-Making in Medieval Art, Cambridge, 1989.

${ }^{57}$ Suzanne Küchler, 'Why Knot? A Theory of Art and Mathematics,' in Christopher Pinney, ed., Beyond Aesthetics. Art and the Technology of Enchantment, Oxford, 2001, 57-

77.

${ }^{58}$ Küchler, 'Why Knot?,' 71.

${ }^{59}$ Küchler, 'Why Knot?,' 73.

${ }^{60}$ Bowden, 'A Critique of Alfred Gell on Art and Agency.'

${ }^{61}$ See, for example, Arthur Danto, 'The Artworld,' The Journal of Philosophy, 61, 1964, 571-84; George Dickie, Art and the Aesthetic, Ithaca, 1964.

${ }^{62}$ See Gell, 'On Coote's “Marvels of Everyday Vision”,' in The Art of Anthropology, 21531. The article by Coote is: "Marvels of Everyday Vision": the Anthropology of Aesthetics 
Published in: Art History Vol. 28 No. 4 (Autumn 2005) pp. 524-51.

and the Cattle-keeping Nilotes' in Jeremy Coote and Anthony Shelton, eds., Anthropology, Art and Aesthetics, Oxford, 1992, 245-73.

${ }^{63}$ See Victor Burgin, 'The End of Art Theory,' in Burgin, The End of Art Theory, London, 1986, 140-215; Craig Owens, 'Representation, Appropriation and Power,' in Owens, Beyond Recognition, Los Angeles, 1992, 88-113.

${ }^{64}$ David Freedberg, The Power of Images, Chicago, 1989.

${ }^{65}$ Wolfgang Kemp, Der Betrachter ist im Bild, Berlin, 1992.

${ }^{66}$ For a general outline of the arguments over the meaning of magic, science and technology see Stanley Tambiah, Magic, Science, Religion and the Scope of Rationality, Cambridge, 1990. The distinctions drawn by Freedberg fall into a sequence of representational 'types' common to many authors. A discussion of these can be found in Richard Parmentier, 'The Pragmatic Semiotics of Culture,' in Semiotica, Vol. 116, 1997, 1114. See especially 63-89.

${ }^{67}$ Walter Benjamin, 'The Work of Art in the Age of its Technical Reproducibility.'

${ }^{68}$ See my 'Iconology of the Interval. Aby Warburg's Legacy,' in Word and Image, 17. 4, 2001, 303-24.

${ }^{69}$ See Julius von Schlosser, Tote Blicke, Berlin, 1993. First published in 1910.

${ }^{70}$ Michel Foucault, The Order of Things, London, 1989.

${ }^{71}$ Roland Barthes, 'The Death of the Author,' in Image, Music, Text, London, 1977; Umberto Eco, The Open Work, Cambridge, Mass, 1989.

${ }^{72}$ See in particular Nietzsche's Birth of Tragedy, Harmondsworth, 1993; Jane Harrison, Ancient Art and Ritual, Cambridge, 1913; Aby Warburg, Images from the Region of the Pueblo Indians of North America, trans. M. Steinberg, Ithaca, 1995. 
Published in: Art History Vol. 28 No. 4 (Autumn 2005) pp. 524-51.

${ }^{73}$ The most celebrated passage on Hephaistos is the ekphrasis of the shield he forges for Achilles in the Iliad (Book XVIII 478-607). On the myth of Daidalos see Susan Morris, Daidalos and the Origins of Greek Art, Princeton, 1995.

${ }^{74}$ Pliny the Elder, Natural History, Harmondsworth, 1991, 330.

${ }^{75}$ See, for example, Ernst Kris and Otto Kurz, Legend, Myth and Magic in the Image of the Artist, London and New Haven, 1979. First published in 1934.

${ }^{76}$ Roland Barthes, 'The Death of the Author.'.

${ }^{77}$ See, for example, Foucault's reading of Las Meniñas in The Order of Things, 3-16; JeanPierre Oudart, 'Notes for a Theory of Representation' in Nick Browne, ed., Cahiers $d u$ Cinéma. Vol. 3: 1969-1972. The Politics of Representation, London, 1990, 203-12 or Bryson, Vision and Painting. The Logic of the Gaze, London, 1983.

${ }^{78}$ For a critique of Barthes see Peter Lamarque, 'The Death of the Author: An Analytical Autopsy,' in British Journal of Aesthetics, 40. 4, 1990, 319-31.

${ }^{79}$ Michael Baxandall, Patterns of Intention. On the Historical Explanation of Pictures, London and New Haven, 1985.

${ }^{80}$ Vasari cited in Anthony Blunt, Artistic Theory in Italy 1450-1660, Oxford, 1940, 90.

${ }^{81}$ Ernst Grosse, Die Anfänge der Kunst, Tübingen, 1894, 9. 